\title{
Enhancing Passive Transport of Micro/Nano Particles into Cells by Oxidized Carbon Black
}

\author{
Kittima Amornwachirabodee, ${ }^{\dagger,}$ Supaporn Khramchantuk, ${ }^{\S}$ Prompong Pienpinijtham, ${ }^{\dagger} \odot$ \\ Nipan Israsena, ${ }^{\S}$ Tanapat Palaga, $\|, \perp$ and Supason Wanichwecharungruang ${ }^{*}, \dagger, \perp \Subset$
}

${ }^{\dagger}$ Department of Chemistry, Faculty of Science, ${ }^{\ddagger}$ Center of Excellence on Petrochemical and Materials Technology, ${ }^{\S}$ Stem Cell and Cell Therapy Research Unit, Faculty of Medicine, "Department of Microbiology, Faculty of Science, and ${ }^{\perp}$ Center of Excellence in Materials and Bio-interfaces, Chulalongkorn University, 254 Phayathai Road, Pathumwan, Bangkok 10330, Thailand

\section{Supporting Information}

ABSTRACT: Uses of micro-/nano-sized particles to deliver biologically active entities into cells are common for medical therapeutics and prophylactics and also for cellular experiments. Enhancing cellular uptake and avoiding destruction by lysosomes are desirable for general particulate drug delivery systems. Here, we show that the relatively nontoxic, negatively charged oxidized carbon black particles (OCBs) can enhance cellular penetration of micro- and nano-particles. Experiments with retinal-grafted chitosan particles (PRPs) with hydrodynamic sizes of $1200 \pm 51.5,540 \pm 29.0$, and $430 \pm 11.0 \mathrm{~nm}$ (three-sized model particles) indicate that only the sub-micron-sized particles can penetrate the first layer of multilayered liposomes. However, in the presence of OCBs, the micron-sized PRPs and the two submicronsized PRPs can rapidly enter the interiors of all layers of the multilayered liposomes. Very low cellular uptakes of micro- and submicron-sized PRPs into keratinocytes cells are usually observed. However, in the presence of OCBs, faster and higher cellular uptakes of all of the three-sized PRPs are clearly noticed. Intracellular traffic monitoring of PRP uptake into HepG2 cells in the presence of OCBs revealed that the PRPs did not co-localize with endosomes, suggesting a nonendocytic uptake process. This demonstration of OCB's ability to enhance cellular uptake of micro- and submicron-particles should open up an easy strategy to effectively send various carriers into cells.

\section{INTRODUCTION}

Drug carriers in particulate forms have been used to solve problems on solubility, stability, and sustained release of drugs and have been applied in both therapeutic and prophylactic purposes. The carrier function is the delivery of various cargoes to targeted cells, and once they reach the targeted cells, it is expected that the carriers should be able to enter those cells and then release drug molecules to perform the intended functions. It has been known that nanoparticles can enter cells through active and passive processes, ${ }^{1,2}$ depending on their physical and chemical properties including size, shape, surface charge, and surface chemistry. ${ }^{3-5}$ Some nanoparticles can enter cells via a nonendocytic pathway (passive transport), ${ }^{6-9}$ whereas many others are taken up into cells by active transport processes in which they have to face cellular elimination and digestion by lysosomal pathway. ${ }^{10,11}$ Nanoparticles with very small size and positive charge have been observed to pass through cell membranes by generating membrane hole or membrane deformation, causing toxicity to cells. ${ }^{12,13}$ The use of amphiphilic molecules (often sold as transfection reagents) that can effectively disrupt phospholipid bilayer membrane assembly and thus allowing many cargoes to pass through the membrane is one of the popular strategy used in many in vitro experiments to bring macromolecules, such as polynucleotides and proteins, into cells. ${ }^{14,15}$ Differently, reports on enhancing cellular penetration of micro-/nano-particles are mostly limited to the use of positively charged materials to fabricate into or to decorate onto the particles. ${ }^{16,17}$ Cell-penetrating peptides are positively charged materials that have been used for this purpose. ${ }^{18-20}$ Nevertheless, there are numbers of carrier systems that cannot be easily decorated with the positively charged moieties; therefore, a simpler means to improve their cellular penetration ability is needed. Ability to send particles into cells will allow the study on cellular metabolism of the particles or materials. Local therapeutic applications of carriers such as topical drug delivery or local prophylactic use, such as vaccine antigen delivery, can also benefit from an ability to enhance the cellular uptake of particles.

We have reported that oxidized carbon nanoparticles (OCSs) can interact with lipid bilayer membranes and can deliver peptide nucleic acids to the nucleus of mammalian cells via endocytosis with endosome leakage. ${ }^{21}$ Distinct superiority of OCSs over oxidized carbon nanotubes and graphene oxide sheets in passing through the phospholipid bilayer membrane has been demonstrated in both artificial cells and real cells. ${ }^{22}$ Recently, we have also prepared new OCSs from commercially

Received: March 15, 2018

Accepted: June 11, 2018

Published: June 25, 2018 
available carbon black particles and showed that these oxidized carbon black particles (OCBs) can directly deliver big functional proteins across cell membranes via a nonendocytic pathway. ${ }^{23}$ Here, we report that these nonimmunogenic, relatively nontoxic OCBs can outstandingly enhance the penetration of both micro- and submicron-sized particles across phospholipid bilayer membranes. We also demonstrate this finding in both artificial cells (giant liposomes) and real cells. The work also includes intracellular traffic of the particles delivered into cells with the aid of the OCBs.

\section{RESULTS AND DISCUSSION}

Preparation and Characterization of OCBs. OCBs (Supporting Information Figure S1) could be successfully prepared by oxidizing carbon black with sodium nitrate and potassium permanganate in strong acid, as previously described. ${ }^{23}$ Scanning electron microscopy (SEM) images indicate spherical morphology with the size of $130 \pm 29.27$ $\mathrm{nm}$, agreeing well with their hydrodynamic size of $127 \pm 1.35$ $\mathrm{nm}$ obtained from dynamic light scattering (DLS) technique. The zeta potential of the particles in water is $-34 \pm 1.75 \mathrm{mV}$. Verification of the particles was carried out by identifying functional groups of the particles by Fourier transform infrared spectroscopy and Raman spectroscopy (Supporting Information Figure S2). The particles consist of epoxy, carboxyl, and hydroxyl functional groups and possess carbon to hydrogen to oxygen molar ratios of 1.0:0.27:0.64 as deduced from combustion-elemental analysis (see Supporting Information Figure S2 for the OCB model particle).

Retinal-Grafted Chitosan Particles. Here, we used the PRPs having various sizes as model particles to investigate an ability of the OCBs to bring particles into cells. We selected these particles because of a few reasons. First, the particles are auto-fluorescent, thus allowing us to monitor them under a confocal laser fluorescence microscope (CLFM). Second, it has been known that chitosan is the polymer that possesses some cellular uptake character, ${ }^{24,25}$ therefore an ability to enhance the particles made from chitosan should demonstrate real interesting efficiency enhancement. Third, because the PRPs (or the so-called pro-retinal particles or PRPs) can be used for therapeutic aspect inside the cells, enhancing their cellular uptake efficiency should have a direct impact for their applications. We prepared the particles as previously described $^{26}$ and used step-wise centrifugation to separate them into three different sizes (Figure 1), $1000 \pm 82.5,500 \pm$ 22.7 , and $390 \pm 15.5 \mathrm{~nm}$, as estimated from their SEM images. These sizes corresponded to their hydrodynamic sizes in water of $1200 \pm 51.5,540 \pm 29.0$, and $430 \pm 11.0 \mathrm{~nm}$ obtained from DLS analysis. All three-sized PRP particles possess similar zeta potential of approximately $50 \pm 0.5 \mathrm{mV}$.

Penetration of PRPs into Cell-Sized Liposomes. The different sized PRPs were tested for their ability to penetrate across the lipid bilayer membrane using artificial cells (cellsized liposomes, see Supporting Information Figure S3 for the lipid structures used for the liposome construction). ${ }^{22}$ The use of the giant liposome makes it possible to focus only on passive transport across the membrane with no involvement from active trans-membrane mechanism. We prepared the artificial cells with dioleoyl L- $\alpha$-phosphatidylcholine using the hydration technique as previously described. ${ }^{22}$ We then incubated the cell-sized liposomes with PRPs and monitored fluorescence signals of PRPs at the inside and outside of the liposomes as a function of incubation time, using a CLFM. We observed that

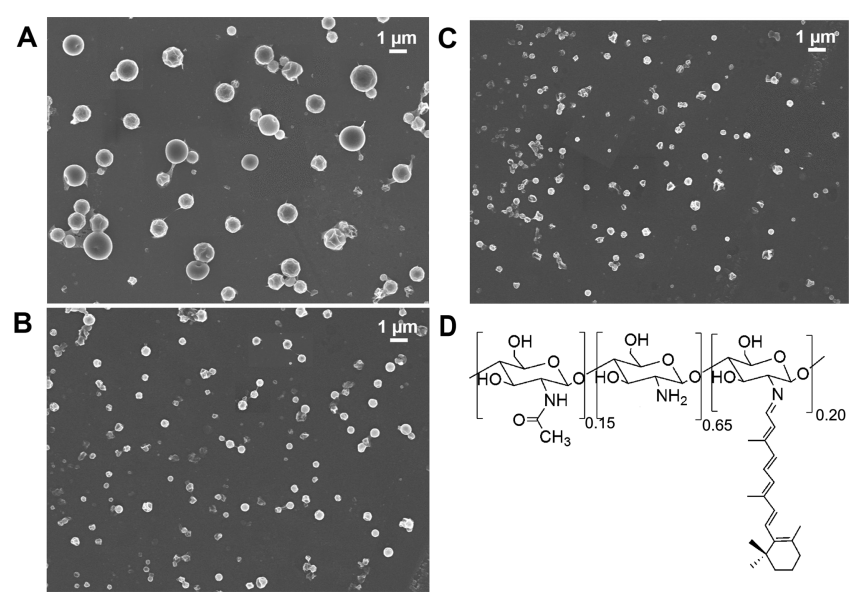

Figure 1. Morphology $(A-C)$ and chemical structure (D) of the three-sized PRPs. SEM images of $1000 \pm 82.5 \mathrm{~nm}(\mathrm{~A}), 500 \pm 22.7$ $\mathrm{nm}(\mathrm{B})$, and $390 \pm 15.5 \mathrm{~nm}$ (C).

the $540 \mathrm{~nm}$ PRPs and the $430 \mathrm{~nm}$ PRPs were adsorbed on the surface of the liposomes after $30 \mathrm{~min}$ of incubation and the two-sized particles could penetrate into the inside of the liposomes after $45 \mathrm{~min}$ incubation (Figure 2). In the case of the $1200 \mathrm{~nm}$ PRPs, the fluorescence signal of the particles on the liposomes was undetectable even after $90 \mathrm{~min}$ of incubation, thus implying minimal to no interaction between the $1200 \mathrm{~nm}$ PRPs and the liposomes. These results indicate that the 430-540 nm-sized PRPs penetrate phospholipid bilayer membranes more effectively than the $1200 \mathrm{~nm}$ PRPs. It should be noted here that most of the prepared liposomes are multilayered liposomes and we observed that during the 90 min incubation time, the penetration of the 430/540 nm PRPs took place only at the first layer. In other words, we did not observe significant penetration of the $430 / 540 \mathrm{~nm}$ PRPs into the interior of the smaller liposomes inside the big liposomes.

Using OCBs to Deliver PRPs into Cell-Sized Liposomes. Here, we tested whether OCBs could increase the lipid bilayer membrane penetration of the PRPs. OCBs and PRPs were mixed at the mass ratio of OCBs/PRPs of $1: 4$ and then the mixture was incubated with liposomes; the fluorescence signal of the PRPs was monitored by CLFM. The results show that in the presence of OCBs, the fluorescence signals of the $1200 \mathrm{~nm}$ PRPs could be observed at the surface of the liposomes within 5 min after incubation and at the inside of the liposomes after $30 \mathrm{~min}$ of incubation (Figure 3). Comparing with the above experiment which was carried out without OCB in which no PRP signal was observed at/in the liposome after $90 \mathrm{~min}$ of incubation, here OCBs not only enabled the $1200 \mathrm{~nm}$ PRPs to associate quickly with the surface of the liposome but also facilitated their penetration into the liposomes' interior. A similar experiment on the 540 and $430 \mathrm{~nm}$ PRPs with OCB addition showed fluorescence signals of the PRPs at the surface and at the inside of the liposomes after only $5 \mathrm{~min}$ of incubation (Figure 3 ). Comparing with $45 \mathrm{~min}$ requirement for the PRPs to penetrate the liposomes when there was no OCB (Figure 2), here the enhancement in penetration rate was very obvious. Therefore, we conclude that $\mathrm{OCBs}$ can enhance the association rate between the giant liposomes and the PRPs of all sizes and can increase the degree of liposome penetration for all three-sized PRPs. 


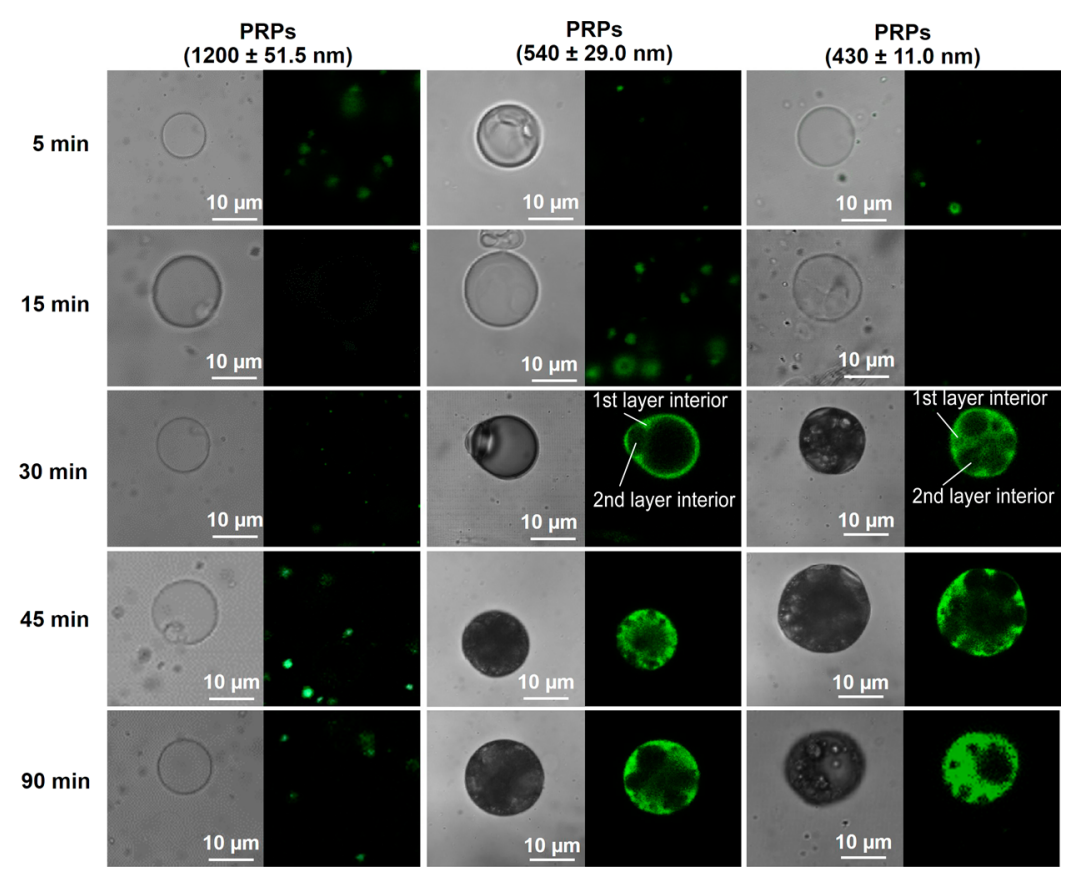

Figure 2. Penetration of PRP micro/nano particles into liposomes without OCB assistance. CLFM images in phase contrast mode (on the left; gray background) and fluorescence mode (on the right; black background; PRP fluorescence shown in green with $\lambda_{\mathrm{ex}} / \lambda_{\mathrm{em}}$ of $488 / 510 \mathrm{~nm}$ ) of liposomes $(0.25 \mathrm{mM}$ phospholipids) incubated with the three-sized PRPs $(100 \mu \mathrm{g} / \mathrm{mL})$ are shown in three columns with the sizes of PRPs indicated on top of the corresponding columns. Images in different rows are those taken at different incubation times as indicated on the left rim of the figure.

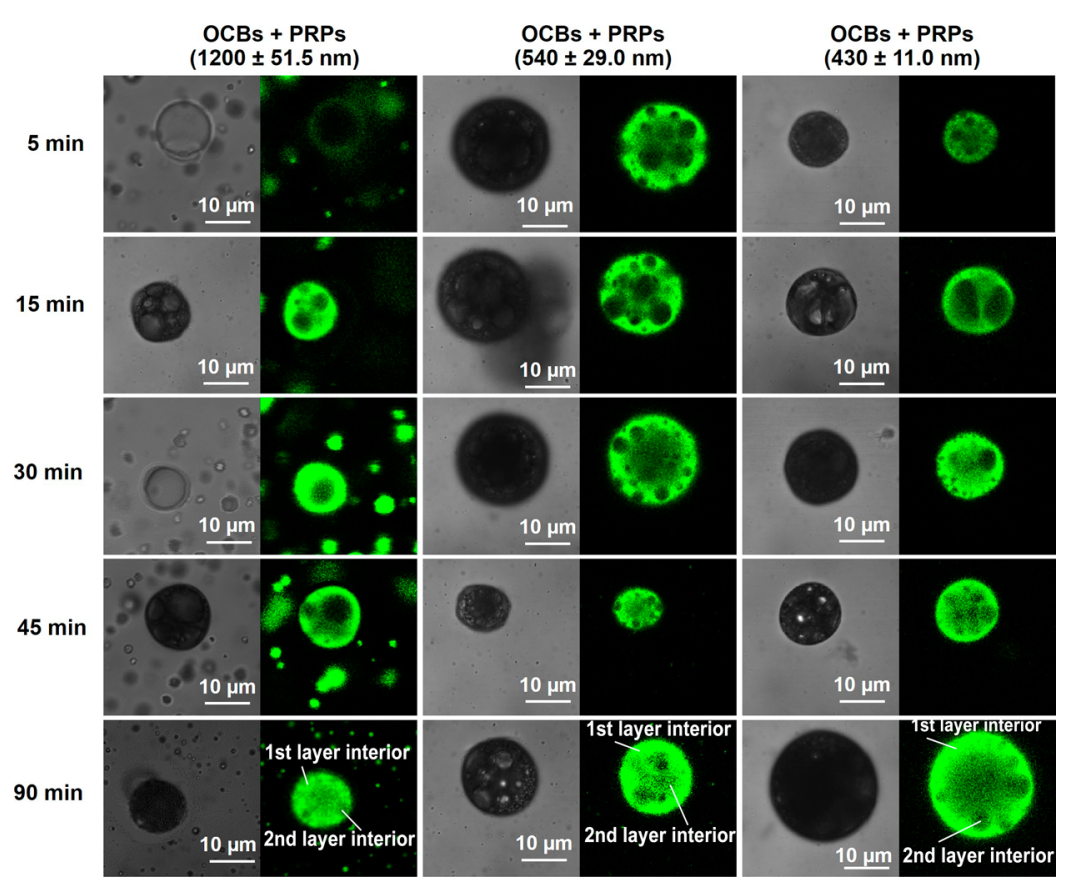

Figure 3. Penetration of PRPs micro/nano particles into liposomes in the presence of OCBs. CLFM images in phase contrast mode (on the left, gray background) and fluorescence mode (on the right, black background; PRPs fluorescence shown in green, $\lambda_{\mathrm{ex}} / \lambda_{\mathrm{em}}$ of $488 / 510 \mathrm{~nm}$ ) of liposomes ( $0.25 \mathrm{mM}$ of phospholipids) incubated with OCBs plus three-sized PRPs ( $100 \mu \mathrm{g} / \mathrm{mL}$, mass ratio of OCBs/PRPs of 1:4) are shown in three columns with the sizes of used PRPs indicated on top of the corresponding columns. Images in different rows are those taken at different incubation times as indicated on the left rim of the figure.

As shown and discussed above that during the $90 \mathrm{~min}$ incubation time, the $430 / 540 \mathrm{~nm}$ PRPs (without OCB) could penetrate only the first layer of the lipid bilayer membrane and therefore could not get into the smaller liposomes located at the interior of the big liposomes. Nevertheless, the addition of OCBs into the system could enable the penetration of all three-sized PRPs across the second-layer liposomes inside the first-layer liposomes. In other words, smaller liposomes inside the big liposomes were also filled with PRPs when OCBs were added (Figure 3, 430 and $540 \mathrm{~nm}$ PRPs at 45-90 min).

To investigate whether OCBs directly interacted with PRPs, here we incubated OCBs with the $1200 \mathrm{~nm}$ PRPs (at the mass 
ratio of OCBs/PRPs of $1: 4$, similar to that used in the above experiments) and subjected the mixture to SEM imaging. It should be mentioned here that if adhering between the two particles was taking place, size change should be observable. Previously, we have used this technique to compare an ability to be adsorbed onto OCB's surface, of different materials. ${ }^{23}$ The SEM image shows no change in size and morphology of the $1200 \mathrm{~nm}$ PRPs (Supporting Information Figure S4), implying that OCBs neither directly adhere to the surface of PRPs nor cause the deformation or size change to the PRPs. To confirm this, we have performed the DLS analysis of PRPs, OCBs, and the mixture of OCBs and $540 \mathrm{~nm}$ PRPs at 1:4 wt ratio. The results reveal the unimodule size distribution with the average sizes of $531 \pm 33.1$ and $141 \pm 15.2 \mathrm{~nm}$ for PRPs and OCBs, respectively. The bimodule size distribution with the averages of $531 \pm 29.1$ and $122 \pm 13.3 \mathrm{~nm}$ was observed for the PRP + OCB mixture (Supporting Information Table $\mathrm{S} 1)$. Interestingly, the average zeta potential value of the mixture system (OCB to PRP at 1:4 wt ratio, zeta potential of $48 \pm 1.5 \mathrm{mV})$ resembles that of the pure PRPs $(50 \pm 0.3 \mathrm{mV})$. This is quite unexpected. To further investigate on this point, we evaluated size and zeta potential of the mixture with a higher ratio of OCBs to PRPs. The bimodule size distribution with maxima at $122 \pm 18.1$ and $531 \pm 24.5 \mathrm{~nm}$ was observed (Supporting Information Table S1). Even at a higher ratio of OCBs to PRPs, we still observed no size change of the PRPs. Zeta potential of PRPs was also unaffected by the increase in the OCB concentration. These results indicate that the negative zeta potential OCBs were not significantly adhering to the positive zeta potential PRPs.

We speculate the hydration shell of OCB and PRP particles act as a barrier that inhibits the direct contact of the two particles. We previously reported that small amphiphilic phospholipid molecules could be adsorbed on to the surface of OCBs. ${ }^{23}$ It is due to the effective adsorption of lipid molecules, which disrupt the local bilayer structure, so that the OCBs can directly induce transient leak on the phospholipid bilayer membranes. ${ }^{23}$ The positively charged phospholipid molecules are small and contain hydrophobic tails that repel water molecules. As a result, adsorption of the lipid molecules on the OCBs can take place in water (not so strong hydration shell around phospholipid molecules). However, PRP particles are a result of polymer self-assembly with entanglement, thus disruption is much harder. In other words, to find nonparticulate PRP polymeric chain (disrupted from the particles) with less hydration shell is very unlikely in the water.

Cellular Uptake of PRPs. To test if OCBs could also facilitate the penetration of particles across cell membrane, we first tested for the cytotoxicity of OCBs in keratinocyte cells at various $\mathrm{OCB}$ concentrations using the MTT assay. The result indicates no toxicity under our experimental conditions at OCB concentrations of up to $30 \mu \mathrm{g} / \mathrm{mL}$ (Supporting Information, Figure S5). Next, we investigated effects of the OCBs on an ability of PRPs to penetrate the cell membrane. Keratinocytes were incubated with the PRPs under two different conditions, with (Figure 4, row 1-4) and without the OCBs (Figure 4, row 5-8), for $24 \mathrm{~h}$. After incubation, the cells were washed and fixed and fluorescence signals of the PRPs in the cells were observed using CLFM. Fluorescence images of the cells incubated with each of the three-sized PRPs without OCB (Figure 4 row 2-4) barely showed fluorescence signals of PRPs in the cells. This result indicates that without OCB, all three-sized PRPs could not significantly penetrate

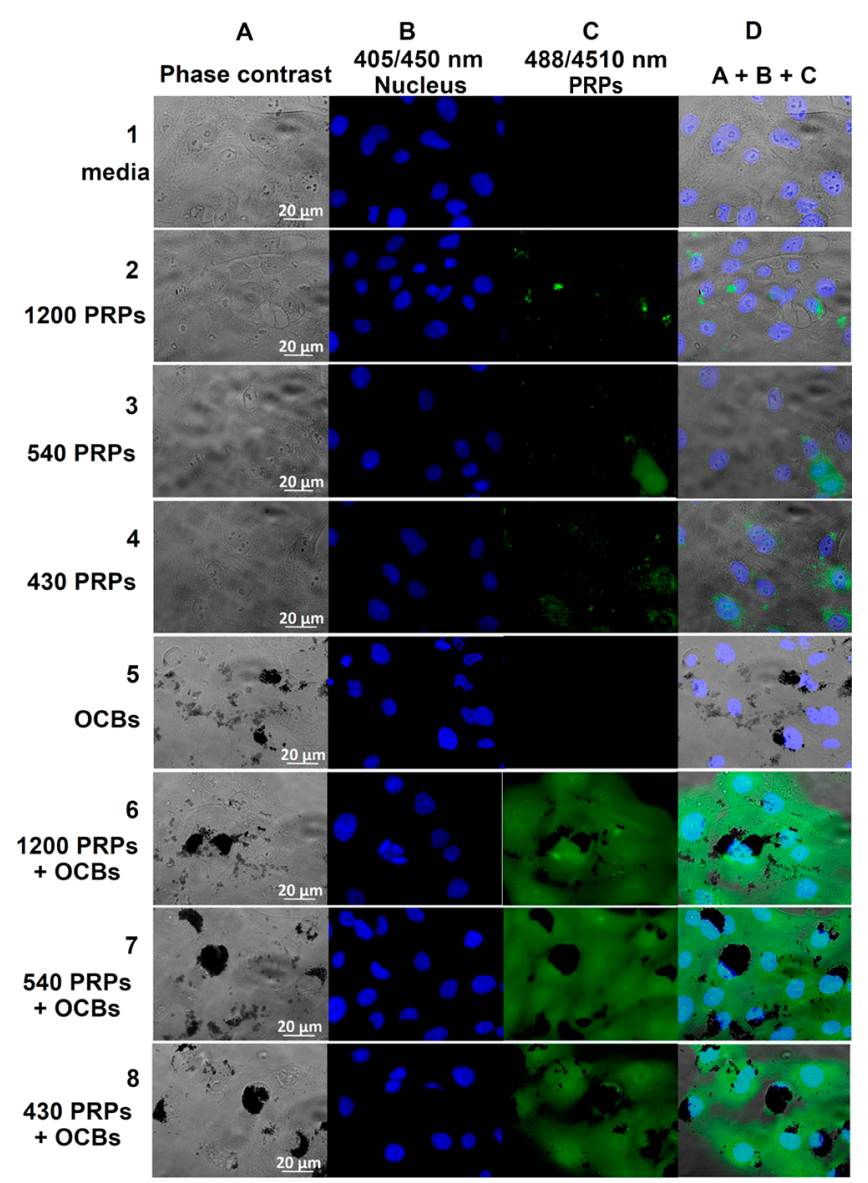

Figure 4. Cellular delivery of PRPs by OCBs. Confocal fluorescence microscopic images of keratinocyte cells after being incubated with media (row 1), $1200 \mathrm{~nm}$ PRPs (row 2), $540 \mathrm{~nm}$ PRPs (row 3), 430 nm PRPs (row 4), OCBs (row 5), 1200 nm PRPs plus OCBs (row 6), $540 \mathrm{~nm}$ PRPs plus OCBs (row 7), and $430 \mathrm{~nm}$ PRPs plus OCBs (row 8 ) for $24 \mathrm{~h}$. Cells morphology images from phase contrast mode are in column A; fluorescence signals of (4',6-diamidino-2-phenylindole) (DAPI; $\lambda_{\mathrm{ex}} / \lambda_{\mathrm{em}}$ of $405 / 450 \mathrm{~nm}$, blue color) are in column B; fluorescence signals of PRPs $\left(\lambda_{\mathrm{ex}} / \lambda_{\mathrm{em}}\right.$ of $488 / 510 \mathrm{~nm}$, green color $)$ are in column $\mathrm{C}$; and merged images of cell morphology, DAPI fluorescence, and PRP fluorescence signals are shown in column D.

into cells. Interestingly, the fluorescence signals from PRPs inside the keratinocyte cells were very obvious when OCBs were present (Figure 4 row 6-8). Without an addition of OCB, the numbers of keratinocyte cells with detectable PRP fluorescence signal were $\sim 9.5 \%$, for all three-sized PRPs. In the presence of OCBs, the numbers of keratinocyte cells with PRP fluorescence in their interior were $\sim 93.6 \%$ for the $1200 \mathrm{~nm}$ PRPs and $\sim 100 \%$ for the 540 and $430 \mathrm{~nm}$-sized particles. These results clearly imply that OCBs can deliver both 1200 and 540/430 nm-sized PRPs into the cells. These results indicate that the PRPs (at the highest tested concentration of 2 $\mu \mathrm{g} / \mathrm{mL}$ ) are nontoxic to keratinocytes even under the condition that the OCBs help increasing their cellular uptake. This nontoxicity of the combined materials in the keratinocytes together with the increased cellular uptake of the PRPs should have an impact on dermatological applications of the pro-retinal nanoparticles. As a result, we next tested for the toxicity of PRPs and OCBs on the three-dimensional (3D) human skin models (EpiSkin, EpiSkin Research Institute, Lyon, France). ${ }^{27}$ The results revealed the cell viabilities of higher than 50\% upon the treatments with OCBs (at the skin 


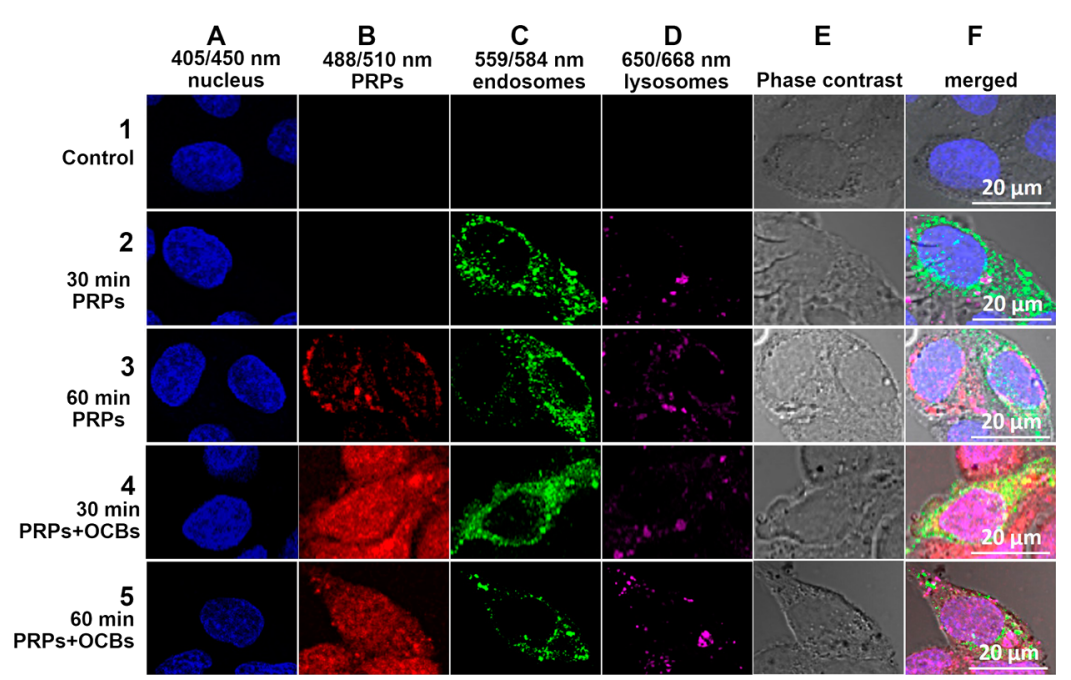

Figure 5. Intracellular trafficking of the $540 \mathrm{~nm}$ PRPs. CLFM images of HepG2 cells after being incubated with media for 60 min (control, row 1), with PRPs for 30 (row 2), and 60 (row 3) min, with PRPs plus OCBs for 30 (row 4) and 60 (row 5) min: fluorescence signals from DAPI $\left(\lambda_{\mathrm{ex}} / \lambda_{\mathrm{em}}\right.$ of $405 / 450 \mathrm{~nm}$, blue, column A), PRPs $\left(\lambda_{\mathrm{ex}} / \lambda_{\mathrm{em}}\right.$ of $488 / 510 \mathrm{~nm}$, red (pseudo-color), column B), early endosome tracker dyes $\left(\lambda_{\mathrm{ex}} / \lambda_{\mathrm{em}}\right.$ of $559 / 584$ $\mathrm{nm}$, green (pseudo-color), column C), lysosome tracker dyes $\left(\lambda_{\mathrm{ex}} / \lambda_{\mathrm{em}}\right.$ of $650 / 668 \mathrm{~nm}$, magenta (pseudo-color), column $\left.\mathrm{D}\right)$, and cell morphology from phase contrast mode (column E), and the merged images of cell morphology, DAPI, early endosome tracker dyes and lysosome tracker dyes (column F).

coverage of $0.96 \mu \mathrm{g} / \mathrm{cm}^{2}$ ), PRPs (at the skin coverage of 0.064 $\mu \mathrm{g} / \mathrm{cm}^{2}$ ), or the OCB/PRP mixture (at the skin coverage of $0.96 \mu \mathrm{g} / \mathrm{cm}^{2}$ for OCBs and $0.064 \mu \mathrm{g} / \mathrm{cm}^{2}$ for PRPs), whereas the cell viability decreased to $8.8 \pm 0.5 \%$ upon the treatment with $5 \%$ sodium dodecyl sulfate (SDS, a positive control, used at the skin coverage of $\left.1.6 \mathrm{mg} / \mathrm{cm}^{2}\right)$. The result here indicates possible application of the OCBs as a nontoxic cellular penetration enhancer for micro-/nano-particulate form of therapeutic agents.

Intracellular Trafficking. We investigated an effect of the OCBs over the intracellular trafficking of PRPs using human liver cancer cell lines (HepG2). We used the $540 \mathrm{~nm}$ OCBs as representative OCBs. The HepG2 cells were incubated with the $540 \mathrm{~nm}$ PRP particles (in the presence and absence of OCBs) for 30 and $60 \mathrm{~min}$, then the PRP locations in the cells were identified through the particles' auto fluorescence signals, whereas the locations of nucleus, endosomes, and lysosomes compartments were determined through the fluorescence signals of the dyes specific to these three organelles (DAPI for nuclei, early endosome-RFP for endosome, ${ }^{28}$ and lysotracker for lysosome ${ }^{29}$ ). CLFM images of HepG2 cells incubated with PRPs (no OCB) for 30 min (Figure 5 row 2) showed no signal of PRP fluorescence in the cells. However, after $60 \mathrm{~min}$ of incubation (Figure 5 row 3 ), the signals of PRP fluorescence were detected at the same locations of fluorescence signals from endosome specific dyes, implying that the PRPs were in the endosomes inside the cells. This indicates that some PRPs were endocytosed into the cells.

When the cells were incubated with PRPs plus OCBs for 30 min, the fluorescence signal of PRPs were detected in cytoplasm and nucleus of the cells (Figure 5 row 4 and Supporting Information video showing a $3 \mathrm{D}$ view of the cell' interior with fluorescence signals indicating locations of PRPs in red, nucleus from DAPI in blue, endosomes from the tracker dyes in green and lysosomes from the tracker dyes in magenta, and Figure S6 in Supporting Information). In addition, here PRP fluorescence locations were related to neither the locations of endosomes nor the locations of lysosomes.
These results imply that the cellular uptake of PRPs in the presence of OCBs is faster and more effective than that in the absence of OCBs. More importantly, with OCBs, the cellular uptake of PRPs does not take place via endocytic pathway.

\section{CONCLUSIONS}

Here, we show that the OCBs not only can speed up the association between 1200, 540, and $430 \mathrm{~nm}$-sized PRPs with phospholipid bilayer membranes of giant liposomes but also can facilitate the PRP penetration across the membrane of the liposomes. Without OCB, the submicron-sized PRPs can slowly penetrate only the first layer of the multilayered liposomes, whereas the micron-sized PRPs cannot penetrate the liposomes. In contrast, in the presence of OCBs, both submicron-sized and micron-sized PRPs can enter all layers of the multilayered liposomes. We also show that without OCB, micron-sized PRPs could not be taken up into keratinocytes, and submicron-sized PRPs could, in a small degree, be taken up into keratinocytes. However, in the presence of OCBs, all of the three-sized PRP keratinocytes could effectively get into keratinocytes. Without OCBs, PRPs enter HepG2 cells via endocytosis; however, in the presence of OCBs, PRPs enter cells via a nonendocytic process and can further translocate to the cells' nucleus. Last, OCBs and OCBs plus PRPs are nonirritating when tested on the 3D skin model. We anticipate that these abilities of OCBs bring micro- and nano-sized particles into cells via a nonendocytic process, to be a starting point for applications of $\mathrm{OCBs}$ as a cellular penetration enhancer for various particulate materials.

\section{EXPERIMENTALS}

Penetration of Micro/Nano Particles into Cell-Sized Liposomes. Two conditions of PRP penetration were observed in this experiment. First, no OCB: the liposome suspension in water was mixed with PRPs $(1200 \pm 51.5,540 \pm$ 29.0 or $430 \pm 11.0 \mathrm{~nm}$, final concentrations of liposomes and PRPs were controlled at $0.25 \mathrm{mM}$ and $100 \mu \mathrm{g} / \mathrm{mL}$, respectively). Second, with OCB: the liposome suspension in 
water was incubated with the mixture of OCBs and PRPs (ratio of OCBs/PRPs as 1:4) at final concentrations of liposomes and OCBs/PRPs mixture of $0.25 \mathrm{mM}$ and $100 \mu \mathrm{g} /$ $\mathrm{mL}$, respectively. After mixing, the suspension was added dropwise onto the glass slide with a silicon chamber. Then, the liposomes in the suspension were observed under a CLFM (Nikon Digital Eclipse C1-Si, equipped with Plan Apochromat VC 100×, BDLaser (MellesGriot, Carlsbad, CA, USA), a Nikon TE2000-U microscope, a 32-channel PMT-spectraldetector, and Nikon-EZ-C1 Gold Version 3.80 software) with $\lambda_{\text {ex }} / \lambda_{\text {em }}$ of $488 / 510 \mathrm{~nm}$.

Cellular Uptake and OCB Delivery of Micro/Nano Particles. Keratinocyte Cell Culture. Preparation of Condition Medium. Mouse embryo fibroblast cells lines (3T3, purchased from American type culture collection, ATCC) were cultured in the mixture of Dulbecco's modified Eagle medium (DMEM, HyClone, Logan, UT, USA) with $10 \%(\mathrm{v} / \mathrm{v})$ of fetal bovine serum (FBS, Gibco BRL Laboratories, Grand Island, NY, USA), $1 \%$ of L-glutamine (Hyclone), and $1 \%$ of penicillin-streptomycin (Gibco). After cells were completely grown, the cells were treated with $10 \mu \mathrm{g} / \mathrm{mL}$ mitomycin $\mathrm{C}$ (Sigma-Aldrich, St Louis, MO, USA) in DMEM without serum for $2 \mathrm{~h}$ at $37{ }^{\circ} \mathrm{C}, 5 \% \mathrm{CO}_{2}$. The mitomycin C-containing DMEM was removed and washed twice with phosphatebuffered saline (PBS), and successively added to $10 \mathrm{~mL}$ of DMEM/F12 (HyClone, Logan, UT, USA) medium with $10 \%$ (v/v) of FBS, $2.5 \mu \mathrm{g} / \mathrm{mL} \mathrm{NaHCO}_{3}, 0.5 \mu \mathrm{g} / \mathrm{mL}$ hydrocortisone (Sigma-Aldrich), $1 \%$ of L-glutamine, and $1 \%$ of penicillinstreptomycin. The cells were cultured at $37^{\circ} \mathrm{C}, 5 \% \mathrm{CO}_{2}$ for 24 $\mathrm{h}$. The culture medium was collected and centrifuged twice at $1000 \mathrm{rpm}$ for $5 \mathrm{~min}$. Then growth factor $[5 \mathrm{mg} / \mathrm{mL}$ human insulin, $20 \mathrm{ng} / \mathrm{mL}$ epidermal growth factor (EGF), Gibco] was added into the supernatant for use as keratinocyte culture medium.

Preparation of Feeder Cells. 3T3 cells were cultured in the mixture of DMEM with $10 \%(\mathrm{v} / \mathrm{v})$ of FBS, $1 \%$ of L-glutamine, and $1 \%$ of penicillin-streptomycin. After the cells were completely grown, the cells were treated with $10 \mu \mathrm{g} / \mathrm{mL}$ mitomycin $\mathrm{C}$ in DMEM without serum at $37^{\circ} \mathrm{C}, 5 \% \mathrm{CO}_{2}$ for 2 h. After the cells were completely grown, the cells were treated with $10 \mu \mathrm{g} / \mathrm{mL}$ mitomycin C in DMEM without serum at 37 ${ }^{\circ} \mathrm{C}, 5 \% \mathrm{CO}_{2}$ for $2 \mathrm{~h}$. The $3 \mathrm{~T} 3$ cells were trypsinized using $0.25 \%$ of trypsin/ethylenediaminetetraacetic acid (EDTA) solution at $37{ }^{\circ} \mathrm{C}, 5 \% \mathrm{CO}_{2}$ for $2 \mathrm{~min}$. To stop the reaction, DMEM-high glucose, $10 \%(\mathrm{v} / \mathrm{v})$ of FBS, $1 \%$ of L-glutamine, and $1 \%$ of penicillin-streptomycin were added and centrifuged at $1000 \mathrm{rpm}$ for $5 \mathrm{~min}$. The supernatant was discarded carefully and re-suspend in $1 \mathrm{~mL}$ of DMEM medium, incubated at 37 ${ }^{\circ} \mathrm{C}, 5 \% \mathrm{CO}_{2}$ for $24 \mathrm{~h}$ to obtain feeder cells.

Preparation of Keratinocyte Cells. Keratinocytes (American type culture collection, ATCC) were grown in the presence of feeder cells in the mixture of DMEM/F12 medium with $10 \%(\mathrm{v} / \mathrm{v})$ of FBS, $2.5 \mu \mathrm{g} / \mathrm{mL} \mathrm{NaHCO}_{3}, 0.5 \mu \mathrm{g} / \mathrm{mL}$ hydrocortisone, $5 \mathrm{mg} / \mathrm{mL}$ human insulin, $20 \mathrm{ng} / \mathrm{mL} \mathrm{EGF,} 1 \%$ of L-glutamine, and $1 \%$ of penicillin-streptomycin at $37{ }^{\circ} \mathrm{C}$, $5 \% \mathrm{CO}_{2}$ for 10-14 days. Then, the cells were trypsinized using $0.25 \%$ of trypsin/EDTA solution and used afterward in the experiments.

Cytotoxicity Test (MTT Assay). Keratinocytes were seeded into 96-well plates coated with $10 \mu \mathrm{g} / \mathrm{mL}$ collagen type I at density of $1 \times 10^{4}$ cells/well in the condition medium at $37^{\circ} \mathrm{C}$, $5 \% \mathrm{CO}_{2}$ for $24 \mathrm{~h}$. After removal of the condition medium, cells were incubated with OCBs at concentrations of $0.1-30.0 \mathrm{mg} /$
$\mathrm{L}$ in the condition medium, for $48 \mathrm{~h}$. After incubation, $10 \mu \mathrm{L}$ of PBS containing $1 \mathrm{mg} / \mathrm{mL}$ MTT solution was added to each well and the plates were incubated for $4 \mathrm{~h}$ at $37^{\circ} \mathrm{C}$. After that, the medium was removed from the wells and isopropanol (200 $\mu \mathrm{L} /$ well) was added to dissolve formazan crystals. The cells were subjected to absorbance measurement at $540 \mathrm{~nm}$ by a microplate reader (Varioskan LUX, Thermo Fisher Scientific Inc., MA, USA). All conditions were tested in triplicate. Cell viability was calculated using the equation below (eq 1 ).

$$
\text { Cellviability }(\%)=\frac{O D_{\text {sample }}-O D_{\text {blank }}}{O D_{\text {control }}-O D_{\text {blank }}} \times 100
$$

Cellular Uptake and OCB Delivery of Micro/Nano Particles into Keratinocytes. Keratinocytes were seeded into 24-well plates on collagen type I-coated cover slips at a density of $1 \times 10^{5}$ cells/well in the condition medium at $37^{\circ} \mathrm{C}$, $5 \% \mathrm{CO}_{2}$ for $24 \mathrm{~h}$. First, we investigated the cellular uptake of micro/nano particles in the absence of OCBs. PRP particles $(1200 \pm 51.5,540 \pm 29.0$ and $430 \pm 11.0 \mathrm{~nm})$ were added to cells at the final concentration of $2.0 \mu \mathrm{g} / \mathrm{mL}$. Second, the cellular uptake in the presence of OCBs was observed by treated keratinocytes with PRP and OCB mixtures. The final concentrations of PRPs and OCBs were 2.0 and $30.0 \mu \mathrm{g} / \mathrm{mL}$, respectively. Then, all of the test plates were left at $37^{\circ} \mathrm{C}, 5 \%$ $\mathrm{CO}_{2}$ for $24 \mathrm{~h}$. The cells, that were washed three times and replaced medium with fresh PBS, were fixed by adding $500 \mu \mathrm{L}$ of $4 \%$ paraformaldehyde and let stand at room temperature for 10 min before being washed with PBS, Then, they were incubated with $200 \mu \mathrm{L}$ of $0.01 \mathrm{mg} / \mathrm{mL}$ DAPI solution for 3 min (to stain nuclei of the cells) and washed with PBS before being subjected to fluorescence microscope analysis (Zeiss Observer Z1, Carl Zeiss Microscopy Ltd., Cambridge, UK.).

Cellular Uptake and OCB Delivery of Micro/Nano Particles into Human Liver Cancer Cells (HepG2). HepG2 were maintained in Roswell Park Memorial Institute medium 1640 (RPMI 1640 medium) with $2.05 \mathrm{mM}$ of Lglutamine (Hyclone Laboratory, Inc., Logan, UT, USA). All of the cells were incubated at $37{ }^{\circ} \mathrm{C}, 5 \% \mathrm{CO}_{2}$ for $24 \mathrm{~h}$. After that, HepG2 were seeded in a 8 -well chamber (Lab-Tek II Chambered Coverglass, NUNC, NY, USA) at a density of 5 $\times 10^{4}$ cells/well, and then $50 \mu \mathrm{L}$ of early endosome fluorescent dye reagent (cellLight early endosome-RFP, Bacmam 2.0, Invitrogen, USA) was added. The mixture was incubated overnight at $37{ }^{\circ} \mathrm{C}, 5 \% \mathrm{CO}_{2}$. Then, the test samples $(540 \pm$ $29.0 \mathrm{~nm}$ PRPs at final concentration of $2.0 \mu \mathrm{g} / \mathrm{mL}$, and $540 \pm$ $29.0 \mathrm{~nm}$ PRPs plus OCBs at final concentration of PRPs and OCBs as 2.0 and $30.0 \mu \mathrm{g} / \mathrm{mL}$, respectively) were added into each well. The plates were incubated at $37^{\circ} \mathrm{C}, 5 \% \mathrm{CO}_{2}$ for 30 and $60 \mathrm{~min}$. At $30 \mathrm{~min}$ before finishing incubation, $50 \mu \mathrm{L}$ of lysotracker deep red (in anhydrous dimethyl sulfoxide, Lysotracker and Lysosensor probe, Invitrogen, USA) was added (final concentration of lysotracker was $200 \mathrm{nM}$ ). Then, the cells were fixed by adding $100 \mu \mathrm{L}$ of $4 \%$ paraformaldehyde and let to stand at room temperature for $10 \mathrm{~min}$ before being washed with PBS. Then, the cells were incubated with $100 \mu \mathrm{L}$ of $0.01 \mathrm{mg} / \mathrm{mL}$ DAPI solution for $3 \mathrm{~min}$ (to stain nuclei of cells) and washed with PBS before being monitored under CLSM (FV3000, Olympus, Tokyo, Japan). Excitations were carried out at 405, 488, 559, and $650 \mathrm{~nm}$, and emissions were monitored at 450, 510, 584, and $668 \mathrm{~nm}$ for DAPI, PRPs, early endosome specific RFP dye, and lysosome specific deep red 
dye, respectively. Data were processed with FV3000-SW software.

Irritation Test of OCBs and PRPs. EpiSkin (EpiSkin Research Institute, Lyon, France) were transferred into $1 \mathrm{~mL}$ of fresh medium and incubated at $37{ }^{\circ} \mathrm{C}, 5 \% \mathrm{CO}_{2}$ for $24 \mathrm{~h}$. After that, $16 \mu \mathrm{L}$ of the test substances $(30 \mu \mathrm{g} / \mathrm{mL}$ OCBs, 2.0 $\mu \mathrm{g} / \mathrm{mL} 540 \pm 29.0 \mathrm{~nm}$ PRPs and the mixture of $2.0 \mu \mathrm{g} / \mathrm{mL}$ $540 \pm 29.0 \mathrm{~nm}$ PRPs and $30 \mu \mathrm{g} / \mathrm{mL}$ OCBs) was applied on tissue and then all tissue was covered by nylon mesh and incubated at room temperature for $42 \mathrm{~min}$. For each sample, duplicate independent experiments were performed. Exposure to test substances were followed by rinsing with PBS and mechanically dried. EpiSkin was transferred to the fresh medium and incubated at $37{ }^{\circ} \mathrm{C}, 5 \% \mathrm{CO}_{2}$ for $42 \mathrm{~h}$ then cell viability was measured by the MTT assay. SDS and PBS were used as positive and negative controls, respectively. For each treated tissue, the cell viability was expressed as percentage of the mean negative control tissue. The mean relative tissue cell viability above $50 \%$ predicted a nonirritancy potential of test substances.

\section{ASSOCIATED CONTENT}

\section{S Supporting Information}

The Supporting Information is available free of charge on the ACS Publications website at DOI: 10.1021/acsomega.8b00487.

Morphology of starting $\mathrm{CB}$ and OCBs; characterization of OCBs; dioleoyl L- $\alpha$-phosphatidylcholine structure used for the liposome construction; SEM image shows morphology of $1200 \mathrm{~nm}$ PRPs after being incubated with OCBs; in vitro cytotoxicity of OCBs in keratinocyte cells; Z-stack image of HepG2 cells after being incubated with PRPs plus OCBs; and size distribution and zeta potential of PRPs and OCBs (PDF)

$3 \mathrm{D}$ view of the cell's interior with fluorescence signals indicating locations of PRPs in red, nucleus from DAPI in blue, endosomes from the tracker dyes in green, and lysosomes from the tracker dyes in magenta (AVI)

\section{AUTHOR INFORMATION}

\section{Corresponding Author}

*E-mail: supason.p@chula.ac.th, psupason@chula.ac.th (S.W.). ORCID ${ }^{\circ}$

Prompong Pienpinijtham: 0000-0002-2956-9132

Supason Wanichwecharungruang: 0000-0002-2802-4341

\section{Author Contributions}

The manuscript was written through contributions of all authors. All authors have given approval to the final version of the manuscript.

\section{Notes}

The authors declare no competing financial interest.

\section{ACKNOWLEDGMENTS}

We gratefully acknowledge the financial provisions of the following: Ratchadapiseksompot Fund (GCRS58032301) from Chulalongkorn University (CU), the Center of Excellence in Materials and Biointerfaces, $\mathrm{CU}$, and the Center of Excellence on Petrochemical and Materials Technology, CU. K.A. is funded by the Royal Golden Jubilee Ph.D. Program (PHD/ 0261/2553), Thailand.

\section{ABBREVIATIONS}

OCBs, oxidized carbon black nanoparticles; PRPs, retinalgrafted chitosan particles; HepG2 cells, human liver cancer cells; OCSs, oxidized carbon nanoparticles; CBs, carbon black

\section{REFERENCES}

(1) Khalil, I. A.; Kogure, K.; Akita, H.; Harashima, H. Uptake Pathways and Subsequent Intracellular Trafficking in Nonviral Gene Delivery. Pharmacol. Rev. 2006, 58, 32-45.

(2) McMahon, H. T.; Boucrot, E. Molecular Mechanism and Physiological Functions of Clathrin-Mediated Endocytosis. Nat. Rev. Mol. Cell Biol. 2011, 12, 517-533.

(3) Verma, A.; Stellacci, F. Effect of Surface Properties on Nanoparticle-Cell Interactions. Small 2010, 6, 12-21.

(4) Tree-Udom, T.; Seemork, J.; Shigyou, K.; Hamada, T.; Sangphech, N.; Palaga, T.; Insin, N.; Pan-In, P.; Wanichwecharungruang, S. Shape Effect on Particle-Lipid Bilayer Membrane Association, Cellular Uptake, and Cytotoxicity. ACS Appl. Mater. Interfaces 2015, 7, 23993-24000.

(5) Seemork, J.; Sansureerungsikul, T.; Sathornsantikun, K.; Sinthusake, T.; Shigyou, K.; Tree-Udom, T.; Jiangchareon, B.; Chiablaem, K.; Lirdprapamongkol, K.; Svasti, J.; Hamada, T.; Palaga, T.; Wanichwecharungruang, S. Penetration of Oxidized Carbon Nanospheres through Lipid Bilayer Membrane: Comparison to Graphene Oxide and Oxidized Carbon Nanotubes, and Effects of $\mathrm{pH}$ and Membrane Composition. ACS Appl. Mater. Interfaces 2016, 8, 23549-23557.

(6) Wang, T.; Bai, J.; Jiang, X.; Nienhaus, G. U. Cellular Uptake of Nanoparticles by Membrane Penetration: A Study Combining Confocal Microscopy with FTIR Spectroelectrochemistry. ACS Nano 2012, 6, 1251-1259.

(7) Mu, Q.; Hondow, N. S.; Krzemiński, Ł.; Brown, A. P.; Jeuken, L. J. C.; Routledge, M. N. Mechanism of Cellular Uptake of Genotoxic Silica Nanoparticles. Part. Fibre Toxicol. 2012, 9, 29.

(8) Geiser, M.; Rothen-Rutishauser, B.; Kapp, N.; Schürch, S.; Kreyling, W.; Schulz, H.; Semmler, M.; Hof, V. I.; Heyder, J.; Gehr, P. Ultrafine Particles Cross Cellular Membranes by Nonphagocytic Mechanisms in Lungs and in Cultured Cells. Environ. Health Perspect. 2005, 113, 1555.

(9) Rothen-Rutishauser, B. M.; Schürch, S.; Haenni, B.; Kapp, N.; Gehr, P. Interaction of Fine Particles and Nanoparticles with Red Blood Cells Visualized with Advanced Microscopic Techniques. Environ. Sci. Technol. 2006, 40, 4353-4359.

(10) Shang, L.; Nienhaus, K.; Nienhaus, G. Engineered Nanoparticles Interacting with Cells: Size Matters. J. Nanobiotechnol. 2014, 12,5 .

(11) Oh, N.; Park, J. H. Endocytosis and Exocytosis of Nanoparticles in Mammalian Cells. Int. J. Nanomed. 2014, 9, 51-63.

(12) Cho, E. C.; Xie, J.; Wurm, P. A.; Xia, Y. Understanding the Role of Surface Charges in Cellular Adsorption versus Internalization by Selectively Removing Gold Nanoparticles on the Cell Surface with a I2/KI Etchant. Nano Lett. 2009, 9, 1080-1084.

(13) Leroueil, P. R.; Berry, S. A.; Duthie, K.; Han, G.; Rotello, V. M.; McNerny, D. Q.; Baker, J. R.; Orr, B. G.; Banaszak Holl, M. M. Wide Varieties of Cationic Nanoparticles Induce Defects in Supported Lipid Bilayers. Nano Lett. 2008, 8, 420-424.

(14) Rösler, A.; Vandermeulen, G. W. M.; Klok, H.-A. Advanced Drug Delivery Devices via Self-Assembly of Amphiphilic Block Copolymers. Adv. Drug Deliv. Rev. 2001, 53, 95-108.

(15) Janes, K. A.; Calvo, P.; Alonso, M. J. Polysaccharide Colloidal Particles as Delivery Systems for Macromolecules. Adv. Drug Deliv. Rev. 2001, 47, 83-97.

(16) Tabata, Y.; Ikada, Y. Effect of the Size and Surface Charge of Polymer Microspheres on Their Phagocytosis by Macrophage. Biomaterials 1988, 9, 356-362.

(17) Yue, Z.-G.; Wei, W.; Lv, P.-P.; Yue, H.; Wang, L.-Y.; Su, Z.-G.; Ma, G.-H. Surface Charge Affects Cellular Uptake and Intracellular 
Trafficking of Chitosan-Based Nanoparticles. Biomacromolecules 2011, $12,2440-2446$.

(18) Deshayes, S.; Morris, M. C.; Divita, G.; Heitz, F. CellPenetrating Peptides: Tools for Intracellular Delivery of Therapeutics. Cell. Mol. Life Sci. 2005, 62, 1839-1849.

(19) Munyendo, W. L. L.; Lv, H.; Benza-Ingoula, H.; Baraza, L. D.; Zhou, J. Cell Penetrating Peptides in the Delivery of Biopharmaceuticals. Biomolecules 2012, 2, 187-202.

(20) Bolhassani, A.; Jafarzade, B. S.; Mardani, G. In vitro and In vivo Delivery of Therapeutic Proteins using Cell Penetrating Peptides. Peptides 2017, 87, 50-63.

(21) Seemork, J.; Sansureerungsikul, T.; Sathornsantikun, K.; Sinthusake, T.; Shigyou, K.; Tree-Udom, T.; Jiangchareon, B.; Chiablaem, K.; Lirdprapamongkol, K.; Svasti, J.; Hamada, T.; Palaga, T.; Wanichwecharungruang, S. Penetration of Oxidized Carbon Nanospheres through Lipid Bilayer Membrane: Comparison to Graphene Oxide and Oxidized Carbon Nanotubes, and Effects of $\mathrm{pH}$ and Membrane Composition. ACS Appl. Mater. Interfaces 2016, 8, 23549-23557.

(22) Arayachukiat, S.; Seemork, J.; Pan-In, P.; Amornwachirabodee, K.; Sangphech, N.; Sansureerungsikul, T.; Sathornsantikun, K.; Vilaivan, C.; Shigyou, K.; Pienpinijtham, P.; Vilaivan, T.; Palaga, T.; Banlunara, W.; Hamada, T.; Wanichwecharungruang, S. Bringing Macromolecules into Cells and Evading Endosomes by Oxidized Carbon Nanoparticles. Nano Lett. 2015, 15, 3370-3376.

(23) Amornwachirabodee, K.; Tantimekin, N.; Pan-In, P.; Palaga, T.; Pienpinijtham, P.; Pipattanaboon, C.; Sukmanee, T.; Ritprajak, P.; Charoenpat, P.; Pitaksajjakul, P.; Ramasoota, P.; Wanichwecharungruang, S. Oxidized Carbon Black: Preparation, Characterization and Application in Antibody Delivery across Cell Membrane. Sci. Rep. 2018, 8, 2489.

(24) Xiao, B.; Ma, P.; Ma, L.; Chen, Q.; Si, X.; Walter, L.; Merlin, D. Effects of tripolyphosphate on cellular uptake and RNA interference efficiency of chitosan-based nanoparticles in Raw 264.7 macrophages. J. Colloid Interface Sci. 2017, 490, 520-528.

(25) Dodane, V.; Vilivalam, V. D. Pharmaceutical applications of chitosan. Pharm. Sci. Technol. Today 1998, 1, 246-253.

(26) Pisetpackdeekul, P.; Supmuang, P.; Pan-In, P.; Banlunara, W.; Limcharoen, B.; Kokpol, C.; Wanichwecharungruang, S. Proretinal nanoparticles: stability, release, efficacy, and irritation. Int. J. Nanomed. 2016, 11, 3277-3286.

(27) OECD, Test No. 439, In Vitro Skin Irritation: Reconstructed Human Epidermis Test Method. OECD Guidelines for the Testing of Chemicals, Section 4; OECD Publishing: Paris, 2015; pp 1-21.

(28) Kim, A. J.; Boylan, N. J.; Suk, J. S.; Lai, S. K.; Hanes, J. Nondegradative Intracellular Trafficking of Highly Compacted Polymeric DNA Nanoparticles. J. Controlled Release 2012, 158, 102-107.

(29) Zhang, C.; Liu, T.; Su, Y.; Luo, S.; Zhu, Y.; Tan, X.; Fan, S.; Zhang, L.; Zhou, Y.; Cheng, T.; Shi, C. A Near-Infrared Fluorescent Heptamethine Indocyanine Dye with Preferential Tumor Accumulation for In vivo Imaging. Biomaterials 2010, 31, 6612-6617. 